\title{
EXPORT FLOOR PRICES IN COCONUT PRODUCTS SRI LANKA EXPERIENCE
}

by

\section{R. MALIGASPE*}

\section{SUMMARY}

1.1 Export Floor Prices for Coconut Products appear to have been introduced in Sri Lanka initially in the late 1960s. Maximising of foreign exchange earnings and prevention of under-invoicing by shippers especially under a tight trade and exchange system at that time and also possible expectation of higher proceeds to millers and coconut producers, appear to have been the main considerations when Export Floor Prices were introduced for most of these Products.

1.2. In the operalion of Export Floor Prices, any decision to introduce, to effect changes or to effect removals in these were made by a Governmental Authority, i.e. the present Coconut Development Authority of Sri Lanka, along with the concurrence of other Governmental Agencies involved. In most instances, such decisions have been made on the initiative of the Trade or the Traders Associations. Local supplyconditions, local costs of production as well as international demand and supply conditions, competitors' prices and availability of substitutes, were the major factors taken into account when making such changes. The Coconut Development Authority had been exerting considerable regulatory controls such as Registration of Export Sales, Limitation of Forward Shipment-Periods, issuing of Export Licences, etc., to effectively maintain these Export Floor Prices.

1.3 Along with the change in Government Policy in 1977, when a liberal trade and exchange system was introduced, the necessity of retaining Export Floor Prices for Coconut Products had been questioned. By August 1981, Expoirt Floor Prices for most of the Coconut Products had been withdrawn. In February 1983, this was re-introduced in respect of Desiccated Coconut the most important coconut product exported from Sri Lanka - and was, working smoothly as long as the international supply was tight, i.e. till around July 1984 . However, with a glut of supplies emerging after this period and due to the Authorities not adjusting their Export Floor Price accordingly for very good reasons, exporters commenced selling under the Floor Price and, therefore, this Floor Price had to be withdrawn. An Export Floor Price for Coconut Oil re-introduced in June 1983 had to be similarly abandoned due to its limited success. As at now, Export Floor Prices exist only for Coir Fibre grades.

1.4 An analysis of the recent operation of the Export Floor Price for Sri Lanka Desiccated Coconut shows that it has been effective as long as it was realistic in terms of international prices and as long as a tight supply-situation prevailed. The FOB Prices actually obtained bad been higher than the Floor Price and close to the international price in such instances, realising the objective of maximising foreign exchange earnings. Naturally, local millers' prices and Fresh Nut producers' prices also remained high in such circumstances. Where supplies were large or where the trade had felt impending supply-increases, the FOB prices had commenced falling whether a Floor Price existed or not. At such times, local miller prices and Fresh Nut prices had also commenced moving down.

\footnotetext{
*Addl. Director/Marketing, Coconut Development Authority, Sri Lanka.
} 
1.5 The existing liberalised export environment in Sri Lanka, where very few products are subject to Export Floor Prices, results in a situation where shippers, if necessary, could circumvent such Floor Prices by under-selling. In such a situation they could meet the difference between the Floor Price and the Actual Sale Price by over-invoicing in imports or purchasing foreign exchange in the black market. The trade structure in Sri Lanka, where the same firms engaged in the export, import and local trading spheres, facilitates them to resort to these activities. Further, the information available to the authorities in Sri Lanka on existing international demand and supply trends, etc. for Coconut Products, is not fully sufficient to adjust the Export Floor Prices as and when the situation warrants it. These background factors have impeded the successful operation of an Export Floor Price in these products.

1.6 Compulsory public auctions and voluntary restraints by Export Agencies have been cited as alternatives to the Export Floor Prices to achiev6 the same objectives. Since these are new concepts untried earlier, only the actual operation of these would reveal whether they are successful alternatives or not. One could even say, Export Floor Prices for Coconut Products could be termed as "an anachronism" in the free and liberal trade atmosphere in Sri Lanka.

Export floor prices or minimum prices or indicative prices as sometimes known could be found in a number of agricultural commodities exported from developing countries and coconut products are not an exception. Such export floor prices have been introduced in these countries mainly to maximise their foreign exchange earnings for which they are urgently in need of, for their day to day imports and for future investments. These floor prices are not uncommon in other coconut producing countries also, but have formed a very important aspect of the Sri Lanka coconut export trade for a considerable period.

\section{HISTORICAL ORIGINS}

Export floor prices in coconut products.appear to have been introduced in Sri Lanka in late 1960's. The establishment of the Coir Fibre Board during this time had created a new wave of enthusiasm among those in charge and among the measures introduced to boost the coir fibre industry was the establishment of export floor prices. Export floor prices for Mattress fibre, Bristle fibre, Twisted fibre, Coir yarn and Coir brushes (Tawashi brushes) had gradually been introduced since then. Export floor prices for Desiccated Coconut appear to have been established somewhere in 1970 . The fightly regulated trade and exchange policy of the then government would have been conducive for introduction of such a measure. The date of introduction of export floor price for coconut oil, the other most important kernel. product exported from Sri Lanka is not clear, but it is presumed that it would have happened during the same period. Floor prices have been prevalent for fresh coconuts, for coconut shell charcoal and for coconut ekels from June 1972, March 1973 and November 1978 respectively.

\section{OBJECTIVES OF FLOOR PRICE SCHEME}

3.11968 to 1972 were years of high production for coconuts and consequently, large exports of all kernel products such as copra, coconut oil, dessicated coconut, poonac etc. were seen. This phenomenon was evident in other coconut producing countries also resulting in lower international prices and consequently lower foreign exchange earnings for Sri Lanka. This inturn had resulted in lower prices for the shippers, millers and the coconut producers. The export floor prices for coconut products appear to have been introduced originally to arrest this declining foreign exchange situation and also to improve the prices obtained by shippers and others down the line. Although the high production years were over after 1972, the Govt. had continued to maintain these floor prices with the original objective still in mind. 
3.2 This objective of maximising foreign exchange earnings appear to have been given the foremost consideration in the floor prices introduced for Desiccated Coconut in 1983 February after its non-existence for about one and a half years. Philippines was the market leader for DC contributing to about 6 Wo of worlds' total exports and to suit its production costs, Philippines had fixed its export floor price at a much higher level than Sri Lanka's. However, to reap the maximum advantage of the fact that both Philippines and Sri Lanka contributed to about $90 \%$ of the total world exports of this commodity, Sri Lanka followed Philippines and fixed its export floor price for DC close to Philippines levels. Later in the paper one could see the advantages accrued to Sri Lanka as well as disadvantages suffered by this move.

3.3 In addition to maximising foreign exchange earnings, the Government at that time which was desirous of having a controlled trade and exchange systern was also concerned about possible under-invoicing by shippers and building up of foreign exchange reserves abroad by individuals to circumvent the tight exchange control regulations introduced. It was expected that export floor prices would prevent such moves by shippers.

3.4 The objective of maintenance of the stability of local prices from the shippers' level to the coconut producers' levels would have been further fuelled by the fact that coconut production was considered as a politically sensitive subject. The Minister in-charge of Coconut Industries prior to 1970 hailed from the coconut belt and there were many politicians of importance from this area who were large coconut estate owners. Such political. interest continued during 1970 to 1977 era also. The continuance of a tightly controlled coconut trade, interalia, through export floor prices was further strengthened by the appointment of a prominent socialist as the Minister in-charge of the Coconut Industries during the period 1970 to 1977.

3.5 Even with the liberalisation in exchange and in trade after 1977, coconut trade continued to be tightly regulated and export floor prices played a prominent role in this. The objective of the maximising foreign. exchange earnings continued as government policy was to export more and earn more foreign exchange in order to absorb the liberalised imports which were increasing rapidly. Maintenance of local shippers' price and producers' price at satisfactory levels appear to have become a stronger objective during this period. Millers of Desiccated Coconut, Coconut Oil and Coir Fibre had become a politically stronger group and there were powerful politicians under this set-up also who hailed from coconut producing areas and who owned large extents of coconut holdings. Naturally they expected higher prices for the miller and the coconut producer and export floor price was expected to be the one sure way of achieving this.

\section{OPERATION OF THE EXPORT FLOOR PRICES}

4.1 In coconut products the pattern had been that in most instances floor price changes had been the outcome of representations made by the trade. There had also been occasions when the Coconut Development Authority itself has been initiating such changes on information received about their necessity but in most of those instances the views of the trade has been sought. However, the Coconut Development Authority (CDA) or earlier the Coconut Marketing Board (CMB) remained the organisation responsible for fixing, changing or withdrawing these prices, although wherever necessary the concurrence of other organisations such as the Ministry of Coconut Industries and the Ministry of Trade and Shipping had been obtained.

4.2 Supply oriented factors such as local availability both spot and forward, local costs of production and demand oriented factors such as international demand for the products, competitors' price, availability of substitutes etc. have been the basic factors taken into consideration when changes in floor prices were made. There had been also instances when the wishes of powerful foreign buyers 
such as the buyer who accounts for about $25 \%$ total mattress fibre exports from Sri Lanka have been taken into account when export floor price changes were made.

4.3 The Coconut Marketing Board and later the Coconut Development Authority had been monitoring extensively the implementation of these floor prices. There had been a package of rules and procedures introduced for this purpose. Immediately a sale was contracted with a foreign buyer it was necessary to register it with the CMB or the CDA. The forward period of the sale was also restricted to 3-6 months as the case may be to maintain the contracted price in spite of any future price changes. The sales so registered had to be supported with copies of contracts to prove their genuineness. When applications for the export licence were received these were checked with the original sale particulars. When shipment was effected it was necessary to submit Bank certified final invoices to the CMB/CDA to prove that the required amount of foreign exchange had been remitted to the country. Although the last, was a legitimate function of the Exchange Control Authorities, the CMB/CDA or their own also checked these as an additional precautionary measure.

4.4 The export floor prices appear to have been in conformity with the existing trade and exchange policy during 1970-1977 period when the whole economy and the trade was tightly regulated. These were retained in the post 1978 era also but very soon it was apparent that these were not compatible with the new free trade environment. Shippers were questioning the wisdom of retaining export floor prices for items such as Ekels, Coconut shefl, Charcoal etc. which were not very important - to the economy. After much agitation export floor prices for Coconut shell Charcoal and Coconut ekels were removed in April 1981. These were soon followed by Coconut Oil in May 1981 and Fresh Coconut in June 1981. The wave of liberalization even swept away the strongest of the coconut export products i.e. dessicated coconut from the floor price scheme in August 198 1. Export floor prices for Dessicated Coconut and Coconut oil were later re introduced. but had to be withdrawn again due to their limited success. At the time of writing only Coir Fibre remained under the floor price scheme (CDA Annual Reviews 1981-84)

4.5 The second phase of the export floor price scheme for D.C. starting from its re-introduction in February 1983, and ending in June 1985 is a clear example of how export floor prices could fail in a liberalized trade climate specially if such prices were not realistic in terms of international prices and local costs. Although 1983 was a good production year the buyers in the international markets had apparently sensed the impending shortage of DC in the year to come and consequently they kept on buying in spite of the floor price introduced in February 1983, which was higher than prices prevailing earlier. In 1983 the Coconut Development Authority increased the export floor price of DC on six occasions starting from USD 770/MT FOB Colombo and ending at USD. 1,365 per MT FOB Colombo in November 1983 (CDA) Annual Review '83). There had been apparently no resistance for these price increases as shown by Reuters quotations for Sri Lankan DC in the London market during the month of November 1983, which stood at US\$ 1436 per long ton CIF U.K. In the year 1984, there were two floor price increases by Sri Lanka ending at US-\$1,455 per MT FOB Colombo in September 1984. However, the situation for DC has changed since second half of 1984. Sri Lanka's DC production and exports have been comparatively high since July that year and consequently large stocks of DC were being acumulated with the major foreign buyers. It would have been possible for these buyers to foresee that Sri Lanka would have a bumper crop of coconuts in 1985 and consequently large quantities of DC being available. As a result they postponed purchases while maintaining the minimum of stocks. At the same time due to high DC prices other natural substitutes and artificial flavours were being used in the end products. Further, other producer countries such as Malaysia, Indonesia and Ivory Coast attracted by high prices for DC increased their supplies. All these resulted in the demand for Sri Lankan DC being gradually diminished. On the other hand the Sri Lankan DC local price also had come down to less than Sri Lankan Rs.20/= per kg. at which price the shippers could sell at a FOB price of about US \$ 1000 per MT. although the floor price stood at US\$ $14551=$ per MT FOB Colombo which fact the foreign buyers were aware of. With large number of 
exporters amounting to over 100 selling DC, there was only one step which an enterprising shipper could take i.e. to undercut and sell. The existing free trade environment in the country was conducive for such an operation. Export floor pfices were prevalent in Sfi Lanka only in respect of 5\% to 8\% of total exports and therefore, it was not difficult to under-sell, but over-invoice and meet the differences between the selling price and the floor price from proceeds on non-floor priced items. The fact that about $90 \%$ of the DC shippers were exporting other non-floor price items also made this operation easy. Further most of them were handling imports also where over-invoicing could help to meet this difference. If all these failed foreign exchange could have been purchased in the black market to meet this difference. In this situation, both the majority of the shippers and the foreign buyers made the best for themselves under the circurnstances, by declaring transactions at the official floor price, but which were actually at a much lower price. It was rumoured that export transactions were taking place about US\$ 200 to 3001= per MT below the official floor price. At thisjuncture the CDA took certain steps to support the export floor price. Introduction of a local floor price, declaration of production quotas for DC mills, and finally a reduction in export floor prices were the remedial measures taken. However, all these measures failed and information was available that actual transactions were still taking place below the floor price. Meanwhile the majohty of the shippers kept on agitating against the export floor price. Taking all these into consideration, the CDA in June 1985, withdrew it.

\section{ASSESSMENT OF EFFECTIVENESS OF FLOOR PRICES}

5.1 The effectiveness of the Export Floor Prices could be judged from to what extent these have realised their objectives. If we take maximization of foreign exchange as an objective, let us see to what extent it has been realised. Tables 1 and 2 below reflect how local and international prices behaved in Dessicated Coconut in 1980 and 1981.

5.1.2. From Table 1. one could observe that in the year 1980, the export floor price for D.C. had been lower than the international price as quoted by Reuters, if one accepts that it is a true indicator of international prices. One could also observe here that during the year the FOB prices had been above the existing floor prices. The swne is true in respect of year 1981 as shown in Table 2. One also could observe that when the export floor price was dropped in August 1981, the FOB price had also started dropping. The Reuters quoted international price for Sri Lanka D.C. in the London Market had also begun to drop. Is this a direct result of the removal of the floor price? When one looks at the fact that the Reuters price for Philippines D.C. in the London Market also begun to drop during this period, one could argue that this drop would have still occurred even if floor prices continued. The fact that one could observe general price drop from about April in this commodity adds strength to this argument. Therefore, one can assurne that when International prices of D.C. are dropping, the removal of Sri Lankan D.C. floor price will quicken this drop. As far as the exported quantities are concerned, it is difficuft to conclude that removal of the floor price contributed to increased exported quantities although figures reveal such increases because histo,rically larger quantities of Desiccated Coconut have been exported from Sri Lanka during the second half of any given year.

5.1.3. Let us see what happened when floor prices for D.C. were operative till they were removed in June 1985. Tables $3 \& 4$ give price figures for two years i.e. 1984 and 1985 respectively.

Table 3 reveals that during 1984 except for the last two months FOB prices remained higher than the floor prices and the international prices as quoted by Reuters had been much higher. However, during the months of November and December both the FOB prices and international price for Sri Lanka D.C. had been lower than the floor price. The same is true for 1985 as shown in Table 4. This leads to the conclusion that floor prices cannot be effectively maintained if they are higher than supply/demand equilibrium price which is indicated by the international price. Regarding quantities 
exported the marginal increase in exports seen after June when floor prices were withdrawn cannot be attributed to this withdrawal but to the fact that during the months of July and August exports of such large quantities are common.

Table 1

\begin{tabular}{|l|c|c|c|}
\hline Year 1980 & $\begin{array}{c}\text { Floor price } \\
\text { US D. per MT }\end{array}$ & $\begin{array}{c}\text { FOB price } \\
\text { US D. per MT }\end{array}$ & $\begin{array}{c}\text { International price } \\
\text { For Sri Lanka DC } \\
\text { As quoted by Reuters } \\
\text { (CIF London) }\end{array}$ \\
\hline January & 1420 & 1407 & 1557 \\
February & 1420 & 1423 & 1575 \\
March & 1420 & 1423 & 1570 \\
April & 1420 & 1435 & 1575 \\
May & 1385 & 1420 & 1574 \\
June & 1345 & 1400 & 1541 \\
July & 1285 & 1357 & 1541 \\
August & 1235 & 1235 & 1450 \\
September & 1245 & 1258 & 1450 \\
October & 1245 & 1260 & 1442 \\
November & 1245 & 1257 & 1442 \\
December & 1245 & 1263 & 1415 \\
\hline
\end{tabular}

Source: CDA Annual Review 1980

Table 2

\begin{tabular}{|l|c|c|c|c|c|}
\hline Year 1981 & $\begin{array}{c}\text { Floor price } \\
\text { US\$ per MT }\end{array}$ & $\begin{array}{c}\text { FOB price } \\
\text { US\$ per MT }\end{array}$ & $\begin{array}{c}\text { International } \\
\text { Price for Sri } \\
\text { Lanka DC as } \\
\text { Quoted by } \\
\text { Reuters } \\
\text { US\$/per Mt } \\
\text { (CIF London) }\end{array}$ & $\begin{array}{c}\text { Quantities } \\
\text { Exporter } \\
\text { MT }\end{array}$ & $\begin{array}{c}\text { International } \\
\text { Price for } \\
\text { Philippine } \\
\text { DC as quoted } \\
\text { By Reuters } \\
\text { US\$ per MT } \\
\text { (CIF London) }\end{array}$ \\
\hline January & 1225 & 1262 & 1422 & 1495 & 1448 \\
February & 1245 & 1274 & 1429 & 1037 & 1430 \\
March & 1245 & 1261 & 1402 & 1216 & 1402 \\
April & 1200 & 1222 & 1345 & 2374 & 1356 \\
May & 1050 & 1191 & 1244 & 2896 & 1277 \\
June & 1050 & 1163 & 1224 & 3549 & 1224 \\
July & 1050 & 1142 & 1115 & 4941 & 1151 \\
August Withdrawn & & 1102 & 1105 & 3581 & 1105 \\
September & - & 1091 & 1060 & 5667 & 1060 \\
October & - & 953 & 984 & 3459 & 984 \\
November & - & 844 & 951 & 3510 & 967 \\
December & - & 784 & 935 & 4777 & 948 \\
\hline
\end{tabular}

Source: CDA Annual Review 1981

5.2. A comparison between the actually realized FOB prices per unit and the internationally quoted prices for these commodities is given in Table 5. One could observe here that in desiccated coconut whether floor prices were prevalent or not the actual FOB price has been close to internationally quoted price (the difference of US\$ 100 - 150 per MT seen in almost all these years is due to the fact 
that the Sri Lanka export price is quoted on FOB basis while international price is quoted on CIF basis). In the year 1982 when there was no floor price it had been still closer to the quoted international price. In coconut oil, however one does not see any uniform pattern. In 1981 where a floor price prevailed till May and in 1982 where there was no floor price, actual FOB price has been close to the intemational price. However, in 1983 the intemational price had been well above the actual price and in 1984 the opposite, may be due to effecting of low priced sales at a time of a rising market and of high priced sales at a time of a falling market. In Coconut poonac, where there was no export floor price the actual FOB price had been always close to the international price with any price difference accounted by the freight component.

5.3. Table 5 shows that if maximising foregin exchange earnings is one major objective in maintaining a floor price, that objective has not met overall because (a) floor prices and actual FOB prices have been below the prevaffing intemational prices for Sri Lankan D.C. except in latter half of 1984 and 1985 which shows that the full advantages of high international prices have not been obtained and (b) at times the opposite had prevailod ie. Export floor prices and the actual prices have been above the international prices which justifies the theory that actual transactions had been artificially kep't above the floor prices through manoeuvring and (c) actual FOB prices for certain other coconut products have been close to international prices irrespective of the fact whether there was a floor price or not.

5.4. When one looks at the gross FOD export proceeds for D.C. annually, the foHowing emerge.

$\begin{array}{ll}1980 & \text { (floor prices prevalent) } \\ 1981 & \text { (floor prices withdrawn Half way) } \\ 1982 & \text { (no floor prices) } \\ 1983 & \text { (floor prices prevalent) } \\ 1984 & \text { ( - do - ) }\end{array}$

S.L. Rs. 716.75 Mil
“ “ $783.56 "$
“ 594.77 "
“ “ $945.22 "$
“ “ $1091.37 "$

(Source : CDA Annual Reviews)

When floor prices were not prevalent in 1982, total export proceeds fell and again increased when floor prices were, re-introduced in 1983. In 1984 it further increased even when exported quantities fell to 30,099 MT from 42,135 MT the previous year. This shows that due to export floor prices, Sri Lankan D.C. exports were able to fetch increased foreign exchange earnings. However whether these floor prices or higher international prices due to whatever reasons may it be, or both contributed to this is a debatable point.

5.5. To what extent export floor prices prevalent in other coconut products such as Fresh Coconuts, Coir Fibres, Coconut Shell Charcoal and Ekels realized the objective of maximising of foreign exchange earnings is difficult to assess as in these products the writer has not been able to obtain proper international price quotations.

5.6. The extent to which the export floor prices helped to stabilize the local Millers' prices and the producers' prices can be ascertained by comparing miller prices and producer prices before and after introduction of selected floor prices or by comparing them before and after withdrawal of such prices. Tables $6 \& 7$ reveal the price levels during the floor price withdrawal of Desiccated Coconut in 1981 and, during the Desiccated Floor Price re-introduction in 1983 respectively.

5.6.1. Table 6 shows that with the withdrawal of the export price actual FOB prices fell and as a consequence, local D.C. Millers' prices also fell. However, the fall in Y.C. Millers' price was shortlived. With the onset of short nut season in November, the Millers' price rose. Similarly, fresh nut producer prices also rose from about September revealing the short supply position. 
These show that the withdrawal of the export floor price did not necessarily reduce the Millers' price and fresh nut producer price. Although, this seems to have had some effect, the local demand and supply factors have played a more dominant role. Therefore, one could conclude that withdrawal of export floor prices by itself had not destabilized local prices in this instance.

Table 3 (year 1984) Source; CDA Annual Review 1984

\begin{tabular}{|l|c|c|c|}
\hline & $\begin{array}{c}\text { Floor price } \\
\text { US\$ per MT }\end{array}$ & $\begin{array}{c}\text { FOB price } \\
\text { US\$ per MT }\end{array}$ & $\begin{array}{c}\text { International price for } \\
\text { Sri Lankan DC as } \\
\text { Quoted by Reuters } \\
\text { US\$ per MT } \\
\text { (CIF London) }\end{array}$ \\
\hline January & & & 1494 \\
February & 1365 & 1317 & 1342 \\
March & 1365 & 1342 & 1520 \\
April & 1365 & 1372 & 1500 \\
May & 1365 & 1399 & 1520 \\
June & 1365 & 1418 & 1623 \\
July & 1365 & 1409 & 1693 \\
August & 1365 & 1438 & 1597 \\
September & $1365-1410$ & 1431 & 1573 \\
October & $1410-1455$ & 1419 & 1536 \\
November & 1455 & 1432 & 1411 \\
December & 1455 & 1439 & 1286 \\
\hline
\end{tabular}

Table 4 (Year 1985) Source: CDA Monthly Bulletin August 1985

\begin{tabular}{|l|c|c|c|c|c|}
\hline & $\begin{array}{c}\text { Floor price } \\
\text { US\$ per MT }\end{array}$ & $\begin{array}{c}\text { FOB price } \\
\text { US\$ per MT }\end{array}$ & $\begin{array}{c}\text { International } \\
\text { Price for Sri } \\
\text { Lanka DC as } \\
\text { Quoted by } \\
\text { Reuters } \\
\text { CIF London }\end{array}$ & $\begin{array}{c}\text { International } \\
\text { Price for } \\
\text { Philippine DC } \\
\text { As quoted by } \\
\text { Reuters } \\
\text { (CIF London) }\end{array}$ & $\begin{array}{c}\text { Sri Lanka } \\
\text { Exports } \\
\text { (MT) }\end{array}$ \\
\hline Jan & 1455 & 1456 & 1290 & 1168 & 3375 \\
Feb. & $1455-1100$ & 1229 & 1140 & 1378 & 3783 \\
March & 1100 & 1088 & 1059 & 1169 & 5024 \\
April & 1100 & 1091 & 1005 & 1269 & 4067 \\
May & 1100 & 1088 & 1075 & 1205 & 3973 \\
June & Removed & 1063 & 1055 & 1239 & 3566 \\
July & - & 856 & 831 & 912 & 4665 \\
Aug. & - & 772 & 779 & 790 & 4838 \\
\hline
\end{tabular}

5.6.2. Table 7 shows that with the introduction of the floor price in February 1983, the FOB price as well as D.C. Millers' price had increased. Similarly, the fresh nut producer price had also increased. So the objective has been realised! However as explained in section 4.5 this was a unique situation where expecting future shortfalls in production foreign buyers made heavy purchases and this demand prompted high local prices. Floor price would have merely helped this tendency, This example also supports the argument that floor prices by itself had not helped to improve to local Millers' price and producer price. But it had lent a supporting role when demand/supply factors lead the price in a certain direction. 
5.7. At present, there are export floor prices for about 18 grades of Coir Fibre and 5 grades of these namely Mattress Fibre, Bristle Fibre/Omat, Bristle Fibre 1 Tie, Bristle Fibre 2 Tie and Hand Twisted Mattress Fibre have local floor prices (Source : Coconut Development Authority). These have been introduced to ensure that the local mills which generate substantial employment opportunities in the Coconut belt receive a remunerative price for their Coir Fibre. According to information received in most instances Fibre Millers had been paid the stipulated local prices or more and there has been hardly any under selling. They generally support these floor prices which ultimately stabilize their income level. In these local floor prices which were operative from around 1970, there. had not been any sharp upheavals but only gradual increases which had helped Millers to absorb their increasing costs. There had not been sharp changes in local production to change this balance in prices. The world intake of fibre has also been more or less stagnant. These had resulted in shippers FOB prices being stable which had helped them to offer a stable price to the Millers. It may also be added that the Millers are a politicafly powerful group who would resort to canvassing their cause if prices fall and this factor had also helped to a certain extent to stabilize these prices.

\section{Constraints in the Implementation of a Satisfactory Floor Price Scheme for Coconut Products}

6. 1. First is the incompatibility of export floor prices to the existing free trade and exchange policy of Government of Sri Lanka. Floor prices are recognized as impediments to exports especially at a time when the government is giving every encouragement to deregulate exports therpby increasing exported quantities and foreign exchange earnings. If floor prices exist, exporters are bound by this additional impediment which prevents thern from quoting freely taking into account market factors such as demand and supply. When the operation of export floor price schernes for coconut products was at its peak it drew a lot of criticism. The Wijeweera Committee appointed by the Government in 1979 to review the policy framework of the Coconut Industry had in a critical tone commented that "In fact compared with other exports, Coconut products are the mostly tightly controlled and regulated. So much so, even the export of Ekels are subject to floor prices" and this clearly echoes the thinking at that time.

6.2 For the successful operation of an export floor price it is not sufficient merely to declare such a price but additional measures such as registration of forward sales, insistence of submission of foreign contracts to authorities, checking whether full value of export consignments have been received to the country etc. should be strictly enforced. Unfortunately the existing free trade environment is not at all conducive to such controls and therefore effective monitoring of export floor prices may be difficult.

6.3 Export floor prices should be realistic in terms of inter national prices if the former are to be meaningful and successful. Unfortunately the authorities in Sri Lanka who are, responsible for the implementation of export floor prices for coconut products do not always have full information necessary to assess the international demand trends such as changes in consumption pattems, etc. and supply trends such as present and future supplies available, extent of competition from present and future, competitors etc. which are vital in the determination of any realistic export floor prices. In such a situation it is inevitable that floor prices become unrealistic to the detriment of the trade. There, had been occasions when shippers of coconut products who are generally against the export floor prices have proclaimed that in spite of the existing floor prices they had no difficulty in selling at lower prices and in the circurnstances such prices were of no use.

6.4 There had been also the criticism that changes to export floor prices have not been made spontaneously when the situation warranted such a change. There it has to be pointed out that the Coconut Development Authority and earlier the Coconut Marketing Board who were responsible for the implementation of export floor prices are duty bound to consider all aspects and consult other 
government agencies wherever necessary before such changes are effected and this type of bureaucratic delay is unavoidable in government decision making.

On the other hand the Central Bank of Ceylon Report (1980) had said that "It appears that one reason for low DC production in the early part of 1980 was the maintenance by the authorities of minimum FOB prices at too high a level which actively discouraged exports. A reduction in the mininum FOB price in the second half of the year led to an increase in production and exports. It is imperative that Sri Lanka maintains a hold on the profitable but highly competitive world market for D.C. Interference in the production and marketing processes may adversely affect this important source of foreign exchange eamings." This shows that even other government agencies were critical of the then existing arrangements.

Table 5

\begin{tabular}{|c|c|c|c|c|c|c|}
\hline & \multicolumn{2}{|c|}{ Desiccated Coconut } & \multicolumn{2}{|c|}{ Coconut Oil in Bulk } & \multicolumn{2}{|c|}{ Coconut Poonac } \\
\hline & $\begin{array}{c}\text { Average } \\
\text { FOB } \\
\text { Price US\$ } \\
\text { Per MT }\end{array}$ & $\begin{array}{c}\text { International } \\
\text { price US\$ } \\
\text { per MT } \\
\text { (CIF } \\
\text { London) }\end{array}$ & $\begin{array}{c}\text { Average } \\
\text { FOB } \\
\text { Price US\$ } \\
\text { Per MT }\end{array}$ & $\begin{array}{c}\text { International } \\
\text { price US\$ } \\
\text { per MT } \\
\text { (C \& F } \\
\text { London) }\end{array}$ & $\begin{array}{c}\text { Average } \\
\text { FOB } \\
\text { Price US\$ } \\
\text { Per MT }\end{array}$ & $\begin{array}{c}\text { International price } \\
\text { (CIF Hamburg) } \\
\text { US\$/MT }\end{array}$ \\
\hline 1981 & $\begin{array}{l}1057 \\
\text { (Floor } \\
\text { price till } \\
\text { August }\end{array}$ & 1188 & $\begin{array}{c}550 \text { (floor } \\
\text { price till } \\
\text { May }\end{array}$ & 574 & $\begin{array}{l}129 \text { (floor } \\
\text { price } \\
\text { operative }\end{array}$ & 193 \\
\hline 1982 & $\begin{array}{l}674 \text { (floor } \\
\text { price } \\
\text { operative }\end{array}$ & 779 & $\begin{array}{l}457 \text { (No } \\
\text { floor price }\end{array}$ & 465 & 132 -do- & 182 \\
\hline 1983 & $\begin{array}{c}953 \text { (floor } \\
\text { price } \\
\text { operative }\end{array}$ & 1180 & $\begin{array}{l}569 \text { (floor } \\
\text { price from } \\
\text { June) }\end{array}$ & 730 & $157-$ do- & 187 \\
\hline 1984 & 1426 -do- & 1525 & $\begin{array}{c}1276 \text { (floor } \\
\text { price } \\
\text { operative }\end{array}$ & 628 & No exports & 156 \\
\hline 1985 & $\begin{array}{l}978 \text { (floor } \\
\text { price } \\
\text { operative } \\
\text { till June) }\end{array}$ & 986 & $\begin{array}{c}550 \text { (No } \\
\text { floor price) }\end{array}$ & 1155 & $\begin{array}{c}77 \text { (No } \\
\text { floor price) }\end{array}$ & 128 \\
\hline
\end{tabular}

Source: CDA Annual Reviews 1981-84 
Table 6 Year 1981 (Source: CDA Annual Review 1981)

\begin{tabular}{|l|c|c|c|c|}
\hline & $\begin{array}{c}\text { DC Export } \\
\text { Floor price } \\
\text { US\$ per MT }\end{array}$ & $\begin{array}{c}\text { DC FOB price } \\
\text { US\$ per MT }\end{array}$ & $\begin{array}{c}\text { DC Millers } \\
\text { Price Rs. } \\
\text { Per Kilo }\end{array}$ & $\begin{array}{c}\text { Fresh Nut producer } \\
\text { price Rs. Per 1000 } \\
\text { nuts* }\end{array}$ \\
\hline January & 1225 & 1262 & 11.84 & 1380 \\
February & 1245 & 1274 & 12.50 & 1470 \\
March & 1245 & 1261 & 13.12 & 1540 \\
April & 1200 & 1222 & 12.33 & 1444 \\
May & 1050 & 1191 & 12.11 & 1250 \\
June & 1050 & 1163 & 12.16 & 1250 \\
July & 1050 & 1142 & 10.43 & 1250 \\
August & withdrawn & 1102 & 10.65 & 1260 \\
September & - & 1091 & 10.60 & 1295 \\
October & - & 953 & 10.00 & 1272 \\
November & - & 844 & 10.54 & 1305 \\
December & - & 784 & 11.11 & 1315 \\
\hline
\end{tabular}

* Annual average exchange rate to US\$ $=$ Rs 19.35

6.5 The structure of the export trade in Sri Lanka has also contributed to the failure of operation of export floor prices forcefully. The trade is composed of large number of exporters. In Dessicated Coconut it is over 100. They differ from each other in scale of operations etc. The larger among; them handle exports of numerous other products where no floor prices exist. They handle imports and also engage in numerous types of trading activities. When circumstances warrant, a considerable number of them would resort to fierce competition among themselves by undercutting each other and sefling below the stipulated floor price. This contrasts to a country like the Philippines where the number of exporters of Desiccated Coconut is supposed to be less than ten and who can be easily controfled in the implementation of an export floor price due to this reason.

6.6. The fofly of sticking on to the export floor prices has not been emphasised clearly by the Wijeweera Committee. It has concluded that "The Committee is of the view that there should be flexibility for exporters to sefl even below the indicative price should they wish to do so. This is for three good reasons. Firstly, indicative prices are also determined by fallible humans and there is no reason to deny the country of an export (if the exporters sense a faffing market) merely because officialdom has erred. Secondly it is normal trade practice for large quantities to be sold at discount and the mere fact that a few have been able to get small parcels sold at a high price is no indication of the correctness of the indicative price fixed. Thirdly, during the glut it is imperative to push out the exports as far as possible and too rigid an insistence on floor price can very well negate such efforts".

\section{Alternatives to Export Floor Prices}

7.1 The foregoing would show that export floor prices in Coconut products had only limited successes in achieving their objectives. Demand and supply factors have been stronger forces in determining whether the originally mentioned objectives were met or not. Here one could argue that export floor prices could be dispensed with easily as they have not fully realized their objectives. However, another could say that if export floor prices realistic in terms of international prices were introduced under a tightly controlled trade and exchAnge environment and if these prices were monitored properly, they would have successfully meet their objectives. Only the implementation of such a scheme for a considerable length of time will help ascertaining whether such a contention is correct or not. 
7.2 A compulsory public auction systern has been suggested by some as an alternative to Export Floor prices. Under such a systern exports of a given product would be allowed only if those had been purchased at the Auctions. At the moment, this is implemented in respect of Copra and Coconut Oil under the Copra Auctions of the CDA. Under such a systern, it is expected that the resultant dernand from a number of sources would help push prices up and exporters would have to ship basing this local cost price into, consideration. The argument is that this would stabilize local producer prices. However, if there is an oligopolistic situation among buyers and a surplus supply, Auction prices would crash. Therefore, a Compulsory Public Auction will not help in such a situation.

7.3 Secondly, one could think of a systern where Governmental Authorities do not impose an export floor price but where the exporters self regulate thernselves through an Association. Under such a systern, only members of the Association would be allowed to export and the Association should ensure that its members do not under-invoice but sell at realistic prices. Any member who is at fault would be expelled from the Association foregoing the right to export. If this scheme works satisfactorily, exports would take place at realistic: international prices and Millers and producers could also, expect to benefit if these prices are passed down. However, this is a method which had not been tried out earlier. Its success; would depend upon to what extent such Associations could be fonned and the extent of discipline these could exert upon their members.

Table 7

\begin{tabular}{|l|l|c|c|c|c|}
\hline & $\begin{array}{c}\text { Floor price } \\
\text { US\$ per MT }\end{array}$ & $\begin{array}{c}\text { FOB price } \\
\text { US\$ per MT }\end{array}$ & $\begin{array}{c}\text { DC Millers } \\
\text { Price Rs. } \\
\text { Per kg }\end{array}$ & $\begin{array}{c}\text { Producer price } \\
\text { Rs. Per 1000 } \\
\text { Nuts* }\end{array}$ \\
\hline 1982 & July & - & 654 & 8.13 & 1015 \\
& August & - & 636 & 7.54 & 1000 \\
September & - & 616 & 7.60 & 1005 \\
& October & - & 612 & 8.00 & 1029 \\
& November & - & 612 & 8.75 & 1100 \\
& December & - & 620 & 8.75 & 1190 \\
& & & & & \\
& January & - & 626 & 9.75 & 1245 \\
& February & $770-860$ & 667 & 13.95 & 1484 \\
& March & 970 & 704 & 15.50 & 1488 \\
April & 970 & 796 & 13.50 & 1267 \\
& May & 970 & 796 & 17.25 & 1285 \\
& June & 1145 & 879 & 20.70 & 1450 \\
& July & 1255 & 899 & 21.50 & 1636 \\
& August & 1255 & 956 & 21.15 & 1633 \\
& September & 1255 & 1034 & 21.17 & 1725 \\
& October & 1255 & 1125 & 24.87 & 2392 \\
& November & 1365 & 1227 & 24.64 & 2945 \\
& December & 1365 & 1289 & 24.16 & 2818 \\
& & & & \\
\hline
\end{tabular}

Source: CDA Annual Reviews 1982 \& 1983

*Annual average exchange rate to US\$ = Rs $20.85-1982$

Rs $23.52-1983$ 
7.4 When we dig further into this question, it could be questioned whether the original objectives of floor price cited earlier in this paper could be termed as objectives any longer. Today, in Sri Lanka foreign exchange is made available for a large number of purposes and consequently there will be little enthusiasm to hold foreign exchange abroad. Secondly, even if export floor prices for Coconut Products prevail, it will be difficult to maintain Miller prices and producer prices at a steady level during a large supply surplus as seen in a number of instances in this paper. Therefore, the answer may be that export floor prices are no longer a necessity. If this contention is correct they could be termed as relics of the past.

\section{REFERENCES}

1. Central Bank of Ceylon - Annual Reports 1980-1984

2. Ceylon Chamber of Commerce - Annual Reviews of Business and Trade 1981-1983

3. Coconut Development Authority Sri Lanka - Annual Reviews 1978-1984

4. Coconut Development Authority- Sri Lanka - Monthly Bulletins 1985 Jan-Sept.

5. Jones, S.F. (1979) - The World Market for Desiccated Coconut Rep Trop Prod Inst. G 129 viii - $91 \mathrm{pp}$.

6. Ministry of Coconut Industries- Sri Lanka Coconut Statistics $1981-1982$.

7. Report of the Committee Appointed to Review the Policy Frarnework Applicable to the Coconut Industry in Sri Lanka; Wijeweera, Eswarathasan and Jayawardena 1979 (Restricted).

8. Reuters Reports on International Coconut Prices - 1980-1984.

9. Sri Lanka Export Development Roard - National Export Development Plan 1983 -1987. 